In the virology sessions, the following review papers deserve special mention: cell systems for the production of viral vaccines (Dr. M. R. S. Iyengar); application of tissue culture in mammalian tumour virology (Dr. J. R. Chowdhury); and plant viruses in plant and insect tissue cultures (Prof. S. P. Raychowdhury).

The plant tissue culture sessions included several review papers and also a numbor of original papers. Among the review papers may be montionod: fertilization of ovules in vitro (Prof. P. Maheshwari and Dr. K. Kanta); chemical induction of polyembryony (Prof. B. M. Johri); morphogenesis in plant tissue cultures (Dr. H. Y. Mohan Ram); and the role of kinetin in the growth and differentiation of plant tissue and organ cultures (Dr. R. L. N. Sastri). Other papers deseribed the culturing of phylloxera gall and crown gall tissues, loaf and callus tissues. Although Prof. H. E. Street (University of Swansea) could not be present at the seminar as expected, his address, entitled "Plant Tissue Culture in an Interesting Condition", was read. In this, Prof. Street pointed out that plant tissue culture investigations are at present entering a critical phase and made a powerful plea for the maximum exploitation of the potentialities of plant tissue cultures.
Profs. C. H. Waddington and H. Katsuta illustrated their papers by means of ciné films of living cell cultures which were of a high technical excellence and most instructive. Prof. J. Paul gave a course of lectures on the techniques and problems of tissue culture with special reference to animal tissue culture, but those interested in plant tissue culture also found many points of interest in them.

Anyone who sat through all the sessions of the seminar would no doubt have gained the feeling that he had been presented with a broad cross-section of the important advances at present being made in the fields of animal and plant tissue culture.

A somewhat novel feature of the seminar was the ad. vance circulation of mimeographed copies of the complete manuscripts of all papers, which facilitated the discussion following the presentation of each paper. The Proceedings of the seminar will be published shortly by Dr. W. Junk, Publishers, Netherlands.

This report would be incomplete without recording the appreciation of the delegates for the excellent arrangements made by the reception committee, with meticulous attention to detail, and for the hospitality extended to them.

\title{
MANAGEMENT STRUCTURE
}

U NDER the title Structure in Management, the National Institute of Industrial Psychology has issued a study by Isabel Blain of different forms and their effectiveness *.

Besides a bibliography, the study includes a note on some earlier studies of management in the United Kingdom. The body of the report is based on an enquiry involv. ing interviews with the chief executives of 24 companies engaged in a wide range of activities and detailed questionnaires completed by more than 1,000 managers at other levels. Generally the methods of description used, while tentative, appear to provide a possible basis for devoloping empirical studies in this field, and the provisional analyses of the features which were observed and their relation to effectiveness as reflected in the views of managers have demonstrated several important points for the future development of such studies.

Many factors likely to influence efficiency have been identified, but their individual effects cannot be simple, and vary according to the ways in which they appear in combination. A wide span of control, for example, may be a handicap where there is little delegation, but appropriate in some other circumstances; the importance of organization charts varies with the size and complexity

* National Institute of Industrial Psychology. Report No. 17. Structure in (It) Blain. ${ }_{10}$. of the organization. Methods of classification developed for other purposes can be misleading if used uncritically in studies of particular problems of management organization.

The operational practices within a company may be as important as structures strictly defined, and managerial posts within any company differ in their structural foatures-for example, in level (nearness to the source of authority or decisions), in responsibility to one person or more, in sharing subordinate staff or not, and in the number of others with whom formal operation links must be maintained. Accordingly, Dr. Blain suggests that resoarch could be developed along two lines. First, a study could be made of the extent to which operational features are important, by comparing companies sufficiently similar in size, number of levels, production systems and proportion of specialists, but differing in respect of organization charts, salary administration or procedures for communication. Secondly, comparisons could be made within particular companies having their own operational characteristics, between managerial positions that differ in their structural features, for example, in responsibility to one person or more. In such ways more intensive studies of comparatively small samples are likely to provide evidence bearing directly on these aspects of the organization of management.

\section{ENDEAVOUR}

A CRITICISM often levelled at British industry in tho vital field of overseas exports is that not enough attention is directed to the importanco of making available technical and commercial literature in the language of the country concerned, especially in Europo. In recont years, with increasing representation of British-made goods in overseas markets, especially at international trade fairs and exhibitions, there has been some improvoment in publicity methods in this important matter, chiefly by the larger industrial organizations, but much more could be done to 'put the message over' to a wider audience of potential foreign buyers in their own language.

To a lessor extent this stricture has in the past appliod to scientific literature, but intornationally modern educational standards havo determined at least a working knowledge of three essential languages--English, French and German -and this makes possible intercourse and understanding on an ever-increasing scale in the fields of the arts and sciences as portrayed in many different countries in as many different languages. The growing availability of Russian texts and scientific literature in English and French is a welcome sign of these modern trends.

A particularly impressive example of a multi-lingual scientific publication, one which has been in existence since 1942, is the journal Endeavour, published by Imporial Chemical Industries, London. This is a review of the progress of science, published periodically in five languages-English, French, German, Italian and Spanish. In Endeavour the emphasis is on British science, but 